\title{
The Legislative Institution of People's Representative Council Aceh (DPRA) in the Formulation of Qanun
}

(Study of Policy Formulation in 2018 Population Qanun Formulation in Aceh Province)

\author{
M. Saleh ${ }^{1}$, Syafei Ibrahim ${ }^{2}$, Kridawati Sadhana ${ }^{2}$ \\ ${ }^{1}$ Doctor of Social Sciences Study Program, University of Merdeka Malang, Indonesia \\ ${ }^{2}$ University of Merdeka Malang, Indonesia
}

\begin{abstract}
The People's Representative Council Aceh (DPRA) is the organizer of the Aceh Government whose members are elected through general elections consisting of national political parties and local political parties. This Legislative Institution has a special name and has 11/4 percent more members than the DPRD of other provinces in Indonesia. The various tasks and authorities carried out by the Aceh Parliament in addition to referring to Law Number 11 of 2006 concerning the Government of Aceh also refer to various legislative products relating to the Regional Government. This research aims to analyze and describe the Legislative Body in the Formulation of the Population Qanun in Aceh, the process of policy formulation in the formulation of the Aceh Population Qanun, and the factors supporting and inhibiting the formal process in the formulation of the Aceh Population Qanun. The approach of this research method is a descriptive qualitative method with research techniques with an interview approach. The results of the study are first, the stages in the process of formulating the qanun are carried out with various stages, starting from the preparation of the Qanun raqan proposal for initiatives from the government / DPRA starting from planning and coordination, forming the committee, the academic committee of the special committee until the discussion on qanun. This is done jointly between the legislature and executive until the plenary discussion. Second is the process of formulation in the formulation of the Aceh population qanun. The implementation of the policy formulation process is carried out by meetings of relevant agencies, jointly conducting consultations with ministries to decide on policy recommendations and monitoring/evaluation. In the process of formulating this policy, it is often hampered by various preoccupations from both the legislative and executive, so that the formulation of qanun takes a long time, out of the plan. The third is the supporting and inhibiting factors in the formulation of the Aceh population qanun, namely the level of education, experience, talent, planning, and coordination as well as information to the public. The inhibiting and driving factors are more on the personal ability of DPRA members from the level of education, experience, coordination, and access to public information so that it influences the process of formulating and implementing policy products that are determined to attract various criticisms from the public.
\end{abstract}

Keywords: Legislative Institution, Qanun Formulation.

\section{INTRODUCTION}

The Regional House of Representatives, both the Provincial and Regency / City DPRDs, as an element of regional government administration have a strategic role. DPRD in carrying out the Legislative function, has now become a phenomenon in many regions, assisted by a DPRD instrument called the Regional Legislation Body (Balegda). The presence of the regional legislative body is needed, so that the performance of the council in carrying out the functions of legislation, budgeting and oversight is more optimal.

The presence of the Regional Legislative Body is to carry out the Legislative function in forming a democratic regional regulation, the DPRD through the Regional Legislative Body carries out the process of forming a Regional Regulation Draft (Ranperda) in two ways, namely the Draft Local Regulation delivered by the Governor, Mayor / Regent through the legal department to the DPRD leader with provide explanations, information and academic texts and subsequently registered in the Regional Legislation Program after previously being considered by the regional legislative body of the DPRD.

In the DPRA Regulation No. 1 of 2014 concerning the Standing Orders of the Aceh House of Representatives article 1 number (14) states that the Legislative Body is a functional grouping of DPRA members to carry out tasks related to the formation / discussion of the draft qanun and other regulations in a planned manner, integrated and systematic. The legislative body is a permanent DPRA instrument and is formed by the board at the beginning of the term of office. While the duties of the legislature 
include drafting a legislation program that lists the order of the draft qanun for 1 (one) 5 (five) year membership period, preparing the DPRA initiative qanun draft based on priority programs that have been set every year.

Amendment of Law Number 23 of 2006 concerning Population Administration to Act Number 24 of 2013 concerning Amendment to Law Number 23 of 2006 concerning Population Administration is a fundamental change in the area of Population Administration[1]. The main purpose of the amendment is to improve the effectiveness of Population Administration services to the community, ensuring accuracy of population data and the excellence of the Population Registration Number (NIK). Following up on changes to the Population Act,

The Minister of Home Affairs of the Republic of Indonesia, on January 29, 2016 issued a circular Number 470/296 / SJ regarding Electronic KTP (el-KTP) valid for life. In this circular, it was stated that continuing Circular Number: 470/327 / SJ dated January 17, 2014 concerning changes in Policy in the administration of Population Administration, as well as paying attention to the mandate of Law Number 24 of 2013 concerning Amendments to Law Number 23 of 2006 concerning Population Administration.

The Minister of Home Affairs of the Republic of Indonesia through Decree 188.34-5186 of 2016, canceled 2 Articles in the Aceh Qanun Number 6 of 2008 concerning the Implementation of Population Administration, namely Article 92 paragraph (3) and paragraph (4) of the Qanun contradicted with 64 paragraph (7) of the Law Law Number 24 of 2013 concerning Amendment to Law Number 23 of 2006 concerning Population Administration which states that "Electronic ID Cards for Indonesian Citizens are valid for life".

Furthermore Article 95; "Matters not yet regulated in this Qanun, insofar as they relate to the authority of the Government of Aceh are further regulated in the Governor's Regulation and to the extent that the authority of the regency / city government is regulated further in Regents / Mayors Regulations in accordance with the Regulations."

Based on the amendment and cancellation of Article 2 by the Minister of Home Affairs and to meet the needs of the community for Population Administration services that are guaranteed by the presence of the state in the Population Administration service, the Aceh Qanun Number 6 Year 2008 concerning the Implementation of Population Administration must be adjusted and perfected. In addition, the amendment to this regulation is also intended to strengthen the institutions of the Aceh Apparatus and the legality of the human resources implementing the Population Administration matters.

It is hoped that with the Changing of the Aceh Population Qanun it can further realize order and legal certainty, realize the welfare and peace of the community, realize governance and social order that guarantees unity in the framework of the Unitary State of the Republic of Indonesia, institutionalize the role and maintain and develop Aceh's special and special features in fostering an orderly culture of Population Administration, and creating an accurate population database as a "basic population data" in cross-sectoral planning. This is one of the concrete steps taken by the Government of Aceh to overcome current and future problems.

This Aceh Population Qanun provides protection, certainty, and recognition of the legal status of every population event and other important events experienced by each resident, requiring an orderly administration of population registration services. Also in the framework of implementing coordination, management, presentation, guidance, coaching, supervision and supervision of Population Administration, activities that are integral, systematic, sustainable and professional are needed.

Based on the fatwa of the Aceh Provincial Main Consultative Council dated November 21, 2006, the implementation of Population Administration is a demand of Islamic Sharia which must be implemented in Aceh. And based on the provisions of Law Number 9 of 2015 concerning Regional Government and Law Number 23 of 2006 concerning Changes in Population Administration as well as other statutory provisions changes occur in the authority and policy of the implementation of Population Administration. Based on the considerations as mentioned above, the Legislation Body needs to establish the Aceh Qanun regarding the Administration of Aceh Population Administration

In the process of strengthening the concept of the Aceh Population Qanun Draft, because it concerns the identity of the Acehnese people, at the beginning there was a complaint from various elements of society, in the Draft Population Qanun it was stated that those who were Acehnese were born in Aceh, and both parents were citizens / from Aceh, this invites a contradiction in how a child born not in the region in Aceh, while both parents are Acehnese, and how parents who are only one of them are Acehnese, it is feared not to be recognized and registered as the people of Aceh, based on This draft Qanun Population.

The results of field observations (observations) or empirical facts on the object of research, there are findings if the Legislative Body of the Aceh House of Representatives in the Formulation of the Aceh Population Qanun, shows indications; (1) The capability of DPRA performance has not been improved in producing policies or Qanun initiatives that more touch the fulfillment of people's lives; (2)L.the level of coordination between the DPRA's tools in preparing and discussing a draft Qanun; (3)P.the Qanun draft discussion process is less transparent, making it difficult to access by the public.

Provisional facts obtained in the planning and coordination process there are still a number of problems in Prolega, the quality of the Qanun produced is inadequate so it does not provide direct benefits for people's lives. Not meeting the target number of completed Qanun Designs, there are still obstacles including the implementation of the Aceh Qanun discussion which is planned based on the annual Prolega and annual fifths. However, this implementation still needs a discussion that needs to be evaluated at 
the top level by the Minister of the Interior or there is no need for further discussion or evaluation. The stages in the policy formulation process in the formulation of the Aceh Population Qanun were carried out in consultation with the Indonesian Minister of the Interior in Jakarta, prior to the Minister of Home Affairs Consultation the Council writes and confirms the arrival of consultations regarding the Population Qanun Draft, but sometimes in the implementation when the consultation at the Minister of Home Affairs is not received by those who have the capacity and quality of the fields related to the Draft Qanun, but is accepted by ordinary employees who do not know and master substance of a draft Qanun.

The Qanun draft discussion process is less transparent, making it difficult to access by the public. In the discussion stage of the Aceh Qanun from starting to process, plan and discuss and validate the Qanun, the time is very relative, sometimes the process is only a few months, but sometimes the discussion and approval takes years.

To refine a Qanun Draft, discussion meetings related to the substance of the Population Qanun were held. In the discussion of the Board also accommodated the aspirations of input related to the Qanun materials from constituents, so that there was an increase in time in gathering suggestions and input, for the improvement of the Population Qanun Draft material. , so the discussion time for the discussion takes even longer. In this implementation there are also inhibiting factors, one of which inhibits community participation which still needs to be evaluated and implemented so that there is a legal reference, while the inhibitors here are the inability of the community and the inability of members of the board in making regulations and discussion of the Qanun Draft as a policy.

Research purposes

1. To analyze and describe the Legislative Body in the Formulation of the Population Qanun in Aceh.

2. To find out and analyze the Policy Formulation Process in the Formulation of the Aceh Population Qanun.

3. To analyze and describe the factors supporting and inhibiting the formal process in the formulation of the Aceh Population Qanun

\section{RESEARCH METHOD}

\subsection{Research Approach}

This research uses a qualitative approach, the approach used by researchers based on data that is stated informant verbally or in writing, and also real behavior, researched and studied as a whole based on facts in the field to find out about the picture The body. Legislation on the Aceh House of Representatives in the formulation of the Aceh Population Qanun. The reason for the qualitative approach can be explained that an approach that is carried out persuasively to informants is needed by researchers in order to obtain information in a dissertation completion.

\subsection{Method of collecting data}

Data collection method with technique purposive sampling, namely by determining the informants themselves who can be interviewed in accordance with the desired needs in research in order to explore the information that is the basis of theoretical design with the existence of research still being carried out within the scope of the Aceh DPR Ban Banleg. Thus the nature of the purpose of selecting a sample in order to obtain information and choose people who allow researchers to study central issues so that they meet the requirements of good informants that is conveying data as it is, honest, pleasant to talk and can communicate well, liked by others, responsible and understanding the object of research including mastering information and being willing to share their knowledge and uphold mutual trust. This interview was conducted with related parties only to support the study of documents. Based on the data sources needed, the data collection method in this study was carried out through: (1). Conduct interviews, (2) Direct observation and (3). Documentation Study.

\subsection{Data analysis technique}

In analyzing the data the author uses a qualitative analysis method which is an analysis that describes the situation and events as a whole with a description conducted by researchers based on legislation, expert views, including the experience of researchers and the author's explanation in the field. The data analysis process is carried out continuously in conjunction with data collection and then continued after the data collection is complete. The reduction process continued throughout the study. Narrative presentation of data after data is obtained from the field through interviews and documents. Withdrawal of conclusions which in principle has been done from the beginning of data collection, where an analyst starts looking for conclusions loosely and openly and then increases to become more detailed and firmly rooted. 


\section{DISCUSSION}

\subsection{Legislative Body of the Aceh House of Representatives in the Formulation of the Aceh Population Qanun}

\section{1) Preparation for DPRA Initiative Proposal Raqan}

The holder of power in the formation of the Qanun is the DPRA together with the Government of Aceh, both of whom have the power to prepare and prepare the Aceh Legislation Program (Prolega). Whereas the validation stage is carried out by the DPRA and endorsed through a DPRA decree.

At the planning stage, the DPRA asks for its equipment called the Legislative Body or Banleg. Banleg in the body of the DPRA has a function as a planning and formation of Qanun. It is stated in article 34 of Law No. 11 of 2006 concerning the Government of Aceh that Banleg has the duty to carry out the formation of prolega. At the provincial level Prolega is implemented by the Aceh Parliament Banleg. Banleg will coordinate from the legislature regarding the policy priorities that will be set forth in the Aceh Legislation Program.

In carrying out its duties, the legislative body conducts intensive coordination with the Government of Aceh, so that the resulting legislation program can be coordinated, directed and integrated. The Aceh Government then requests the Bureau or Section related to the laws and regulations in this case the Legal Bureau be appointed. Furthermore, the Legal Bureau will coordinate with the Executive Board regarding the policy priorities that will be set forth in the Aceh Legislation Program.

Coordination conducted by the Legal Bureau in the executive ranks is carried out with the following discussion agenda. First, setting priorities. In setting the priority scale is adjusted to the basic needs in accordance with the current dynamics of society. The second is synchronization and harmonization of regional legal products with due regard to hierarchy, public interest based on Islamic law. Then, third, also discussed about public participation in the preparation, discussion, monitoring both in the making and implementation. And fourth, improvements were made, changed, and updated qanun that was not in line with Law No. 11 of 2006 concerning the Government of Aceh and the needs of the community and Islamic law[2].

Coordination between the Aceh DPR and the Government of Aceh is carried out through the joint preparation of the Aceh Legislation Program which is made at the beginning of the annual period according to real needs. In the process of an agreement to make the Aceh Legislation Program a DPRA and the Aceh Government jointly submit a draft Qanun, then select and / or be integrated into an agreement between the two. This agreement is about the Aceh Legislation Program, both 5 (five) years as well as those for annual priorities as outlined in the DPRA's decision.

The draft Qanun was proposed to the legislative body then the legislative body together with the DPRA jointly discussed the Qanun by coordinating with commissions in the DPR and the Aceh government. In the discussion it can be seen the stages of making Qanun. One of them is the discussion of academic texts discussed with the legislative body involving all elements of SKPA's legal experts and academics.

Before the stipulation of Prolega, Banleg sent a letter back to the DPRA leadership to report or submit the results of the Prolega appointment meeting with an explanation of how many proposed Qanuns and which Qanuns were included in Prolega. Later the DPRA leadership immediately brought the proposal to the deliberation meeting and then reassigned to the Qanun discussion with a decision whether the Qanun was discussed by the commission or formed by the Special Committee or even formed a working team. Then the commissions or special committee appointed to discuss the Qanun by inviting relevant parties who proposed the title of the draft Qanun by involving the legal Bureau, the Government of Aceh, SKPA, Organization Bureau.

All policy plans in the legislation program are a list of plans that have a common thread - a clear link. More important is reflecting the big vision of a country or region.

The result of this coordination was born from a conception from the Aceh DPR. Then Banleg and the Legal Bureau coordinated the synchronization of each conception in order to come up with a joint Legislation Program that had been approved by the head of government (Governor). After obtaining approval with an internal mechanism in the government, the joint draft was ratified through the DPRA plenary meeting and gave birth to the Aceh DPR Decree.

After this the draft Qanun proposal will be known and discussed together with the Executive (Government / governor), including the Legal Bureau and the Government development Bureau. In the end the Qanun-qanun agreement was born, what was prioritized for one year. Besides also whether there is a possibility of tentative schedules and priority scale is important to be discussed and proposed again to the governor and discussed.

After gathering information and advice from the public, the next step is to build priorities. If there are limitations to natural resources in the personnel environment of DPRA members, budget constraints, time constraints, then these constraints must be immediately solved together. The scale of priorities is also very important to be determined in order to determine the direction of future policies. Preparation of qanun priorities is actually very closely related to political issues. This chapter is not merely a technical matter because it concerns the basic needs of the community. In compiling the criteria, the level of sensitivity of DPRA members is needed in terms of capturing the dynamics that develop in the community, so that pro-people regulations will be born later. 
There is one mechanism that can be carried out by the DPRA and the Government, namely the Annual Evaluation Prolega. This evaluation has not been contained in the policy regarding Prolega so that its nature may or may not be carried out. This evaluation is useful to reflect legislation activities for the past one year. Also reflecting on the constraints faced both in terms of the quantity of qanun produced also from the current political, economic and cultural constellations that developed in Aceh. Furthermore, this evaluation is also useful for designing new strategies (new design) that will be used in developing Prolega going forward.

2) Academic Paper Making

Academic texts are the raw materials needed in the formation of legislation, including Qanun (regional regulations). With the support of an adequate academic paper, it is expected that good legislation can be formed, in an applicative and futuristic sense.

It was further explained that Article 56 paragraph (2), Law Number 12 of 2011 concerning Formation of Regulations (as a substitute for Law Number 10 of 2004) stipulates the "Draft Qanun (Regional Regulation) of the Province as referred to in paragraph (1) accompanied by an explanation or statement and / or Academic Paper ". The inclusion of the clause "... and / or ..." has an impact on the lack of firmness in making Academic Manuscripts in the process of making the draft qanun (regional regulations). This is very unfortunate because the Academic Manuscript should be seen as a crucial thing rather than as a partial thing from making a draft regulation, because in making the Academic Manuscript will be carefully loaded philosophical, sociological and juridical basis as a good basis for a draft[3].

Obstacles arise if in a local government does not have enough funds to make Academic Manuscripts by a competent party in a field related to the draft that will be made. In the discussion it was stated that the Academic Manuscript as a result of scientific formulation does not require the author to come from the tertiary level, but can also be produced by holding a seminar that invites speakers, experts / experts who are competent in making a related draft.

Hasbullah Fudail is of the opinion that making Academic Manuscripts by providing seminars can minimize the costs incurred, as well as provide a way out for local governments that do not have competent academics in a particular field in their area. Some of these things that often make Academic Manuscripts ruled out in the making of the plan qanun (raqan).

There are two important mappings in the formation of law-level rules even though they are rarely done thoroughly (Siedman): First, the extent to which academic studies explain the symptoms of a social problem that will be regulated by qanun. Explaining the symptoms becomes meaningless if not accompanied by exposure to facts. The process of obtaining facts, in the academic world, must pass through a scientific framework, so that others can criticize the facts presented. Second, academic studies must identify various actors whose behavior will become a social problem. That is, with certain methods and mechanisms, academic studies will be able to map important actors who are likely to become problems [4].

Regarding population data, what is important is related to broad population data. One of them, is knowing the total population in Aceh, in which it outlines social welfare, which includes employment, education, income, and various other activities. The aim is to facilitate the government in mapping out various problems which are then implemented through various programs, both in the fields of education, health, and other social fields.

\section{3) Submitting the draft Qanun}

The draft Qanun is the basic concept of drafting regional regulations that contain academic papers on the results of scientific studies along with the initial draft of proposed regional regulations. The draft Qanun is almost the same as the law making process. The qanun design process also goes through two channels, namely the executive proposal (Regional Government) and the legislative proposal (DPR Aceh). During the autonomy policy rolling, legal instruments from the central government used as a basis or reference in drafting regulations at the regional level.

The draft Qanun can come from the Aceh House of Representatives or the Government. If in one session the Governor and the DPR of Aceh deliver the draft Qanun with the same material, then what is discussed is the Qanun draft submitted by the Aceh DPR, while the Qanun draft submitted by the Governor is used as a comparison material.

The draft originating from members, at least submitted by 5 members as initiators who come from 2 (two) or more factions. The proponent reported the plan to draft a pre-draft Aceh qanun to the leadership of the DPRA accompanied by a full explanation of the concept of the qanun draft arrangement which includes:
a. background and purpose of the preparation;
b. Legal Basis;
c. goals to be realized;
d. main idea, scope or object to be arranged;
e. range and direction of arrangement and;
f. linkages with legislation.

Pursuant to Law Number 12 of 2011 concerning Formation of Regulations and Regulations explaining the philosophical, sociological and juridical basis described in Appendix 1 Chapter IV page 6 as follows: 


\section{a. Philosophical Basis}

The philosophical foundation is a consideration or reason that illustrates the regulations formed by considering the outlook on life, awareness, and legal ideals which include the atmosphere of mysticism and the philosophy of the Indonesian nation which originates from the Pancasila and the Opening of the 1945 Constitution of the Republic of Indonesia.

\section{b. Sociological foundation}

Sociological foundation is a consideration or reason that describes the regulations that are formed to meet the needs of the community in various aspects. The real sociological foundation concerns empirical facts about the development of problems and the needs of society and the state.

\section{c. Juridical Basis}

Juridical foundation is a consideration or reason that illustrates the regulations that were formed to overcome legal problems or fill the legal vacuum by considering existing rules, which will be amended, or which will be revoked to ensure legal certainty and a sense of community justice. Juridical foundation relates to legal issues related to the substance or material that is regulated so that new legislation is needed. Some legal issues are, among others, regulations that are outdated, regulations that are not harmonious or overlapping, types of regulations that are lower than the Law so that the force is weak, the rules already exist but are inadequate, or the regulations do not yet exist.

In the material aspect of qanun, it is expected to be able to contain material that is responsive to the interests of the people, protects human rights and contains the values of eternity. Besides that, Qanun material needs to be compiled by adhering to the principles of protection, humanity, nationality, kinship, characteristics, diversity, justice, non-discrimination, equality of position in law and government, order and legal certainty as well as balance, harmony, participation and harmony.

While in the aspect of legal apparatus, integrity, morals and professionalism are needed, which can support the realization of strong and integrated legal institutions. Problems in the legal material, facilities and infrastructure have an impact on the issue of community legal awareness, namely the low public trust in the law marked by broken relationships or a gap between legal norms and community behavior.

The draft Qanun that has been prepared by the Aceh DPRD was submitted by the DPRA Chairperson to the Governor. Furthermore, the dissemination of the Draft Qanun originating from the DPRA initiative was carried out by the DPRA Secretariat. Discussion of the draft Qanun in the DPRA is carried out by the DPRA together with the Regional Head (Governor) through a level of discussion which includes:

a. First level;

(1) Explanation of regional heads in the plenary meeting on the submission of the draft Qanun originating from the regional head.

(2) Explanation of the Chairperson of the Commission / Joint Commission or Special Committee in the plenary meeting on the submission of the draft Qanun originating from the DPRA

b. Second level;

(1) In the case of the draft Qanun originating from the region:

(2) General view of factions

(3) Answer from the Regional Head

(4) In the case of the draft Qanun coming from the DPRA:

(5) Opinion of the Regional Head

(6) The answers from the factions

c. Third level;

Discussions in Commission / Joint Commission meetings or Special Committee Meetings with the Regional Heads or Designated Officers.

d. Fourth level;

Decision making in plenary meeting which is preceded by:

(1) Report on the results of the third round of talks:

(2) Faction end opinion:

(3) Decision-making

\subsection{Policy Formulation in the Formulation of the Aceh Population Qanun:}

Population management is closely related to development discussion, because every development is certainly a planned way of directing population development within the scope of development. Development growth is closely related to population growth in an area.

"The population is every person, both Indonesian citizens and foreigners who reside in the territory of Aceh Province." and "Acehnese population is any person who resides permanently in Aceh regardless of ethnicity, race, religion, and descent." (Aceh Qanun No. 6 of 2008 concerning Administration of Population Administration)[5]. 
According to the Aceh Qanun Regarding the Implementation of Population Administration, Population Administration is a series of structuring and controlling activities in the issuance of population documents and data through population registration, civil registration, Marriage Registration for Muslims, management of population administration information and utilization of the results for public services and development.

This Qanun regulates: general provisions; principles and objectives; rights and obligations of the population; ID number; birth registration; KK issuance; issuing ID cards; issuance of certificate of residence; rectification and cancellation of KK and KTP; revocation of KK and KTP; Legalization of KK and KTP; registration of population events; change of address; registration of move comes in and outside the region; reporting arrivals and guests; the principle of civil registration; birth registration; reporting population births outside the territory of the Republic of Indonesia; recording the birth of Indonesian citizens taking place over the sea; birth registration of Indonesian citizens and foreigners; marriage registration; marriage registration based on court decision; recording of marriages between foreigners; Indonesian citizen reporting outside the territory of the Republic of Indonesia; recording of marriage cancellation; recording divorce and cancellation; registration of death; recording of adoption of children; recording of name changes; recording changes in citizenship status; recording of other important events; rectification and cancellation of civil registration; issuance of excerpts from the new civil registration certificate; data collection on vulnerable population administration and residents who are unable to report themselves; investigation; administrative sanctions and service fees; criminal provisions and transitional provisions.

Population administration is a complex activity because it involves many agencies and interests. From several related agencies, the Ministry of Home Affairs is the leading sector in population affairs. This departmental policy reflects the population administration policy in Indonesia. In addition, the implementation of this policy can be seen from the administration of population administration in the Provincial and Regency / City Local Governments which are agencies under the coordination of the Ministry of Home Affairs.

In the process of policy formulation, the formulation of the problem becomes the first indicatora before the policy formulation process continues to the next stage. This also applies to the formulation of the Aceh Population and Administration Qanun which is of course the formulation of the problem is something that must be passed by the stakeholders formulating the Aceh Population and Administration Qanun.

Paand when the formulation of the Aceh Population and Administration Qanun was carried out, of course there were several things that made the issue in society in the Aceh Administration and Population Qanun so that this issue or issue was immediately discussed together by the Qanun designers in this case the Aceh Administration and Population Office, as the party executive, Aceh People's Representative Council (DPRA) as the legalization of policies and various elements of community groups. This was done with the aim of ensuring that a Qanun that would be formulated did not conflict with applicable law. Then as an effort to synchronize the Aceh Administration and Population Qanun with the National Population Act.

It can be concluded that all institutions and communities are involved in the formulation of the Aceh Population Qanun, and do not miss the Regional Office of the Ministry of Law and Human Rights in the formulation of problems in the Population Qanun formulation as it should, this is also the design team of the Regional Office of the Ministry of Law and Rights Aceh's Human Rights are included by the Regional Government and the Aceh Regional Representative Council (DPRA) starting from the initial planning stage or problem formulation

1) Formulation of Alternative Qanun Designs.

PaIn the stage of selecting these policy alternatives, several alternatives were produced during the formulation of the Qanun Administration and Population process starting from the problem formulation stage to the policy agenda stage. In the Aceh Administration and Population Qanun itself there are four alternatives obtained and then from the alternatives available, the alternatives chosen were agreed upon by the qanun drafting actors in this case the drafting team for the Administration and Population Qanun.

So.As stakeholders, the designers of the Aceh Population and Administration Qanun certainly have chosen several alternatives that make the main urgency to be discussed as a problem solver or issue that develops in the people of Aceh Province. Some alternatives contained in the formulation of the Aceh Population and Administration Qanun along with an explanation and the purpose of the alternatives can be seen in the table below.

Table 1. List of Alternatives for the Aceh Population and Administration Qanun

\begin{tabular}{|c|l|l|}
\hline No & \multicolumn{1}{|c|}{$\begin{array}{c}\text { Alternative Qanun for Aceh Administration and } \\
\text { Population }\end{array}$} & \multicolumn{1}{c|}{ Information } \\
\hline 1 & ID number & As a Code of Population Administration \\
\hline 2 & Civil registration & As the Identity of the People of Aceh \\
\hline 3 & $\begin{array}{l}\text { Population Registration and Civil Registration at a Time } \\
\text { of Emergency and Extraordinary }\end{array}$ & $\begin{array}{l}\text { In exceptional circumstances to make data collection namely } \\
\text { natural disasters, or war }\end{array}$ \\
\hline 4 & Population Information System & Management of Information Systems for Social Welfare \\
\hline
\end{tabular}


From the explanation of the alternative table of the Aceh Population Qanun or in another sense is the mechanism in managing the social welfare data above related to the formulation of the Aceh Population Qanun, the Aceh Government that the alternatives chosen for further discussion are several administrative and population management mechanisms in Aceh to understand the conditions of the Acehnese people both population, economic, social and cultural. Of course, the selection of several administrative and population alternatives in managing social welfare data as shown in the table has gone through a very long process and is an urgency that must be reviewed immediately for the formulation of the Aceh Administrative and Population Qanun.

2) Policy Recommendations.

PeThe policy formulation for the Aceh Population and Administration Qanun was carried out by the Aceh People's Representative Council (DPRA) through a plenary session attended by elements of the government represented by the Aceh Population Service. The stipulation was also invited by various relevant agencies and community groups involved in the preparation of the Qanun. At the time of the stipulation of Qanun as regulated in Law Number 12 of 2011 concerning Formation of Regulations and Government Regulations Number 59 of 2015 Concerning Participation of Drafting of Legislation in Formation of Regulations and their Guidance[6].

SecaIn general, the relevant stackholders have been involved to the maximum extent as mandated by Law Number 12 of 2011 concerning the Formulation of Qanun. However, coordination needs to be improved so that the qanun process that is made and formulated requires input, suggestions and criticisms, so that the process runs well, not being delayed in accordance with what was agreed upon when making a joint agreement in terms of the formation of the Qanun.

PeMaximum level of related institutions is the key for a regulation and policy to run well without having to be debated when the implementation is carried out especially in particular the involvement of the draft legislation team, because with such involvement the formulation of policies is in accordance with the direction and does not conflict with national regulations.

\subsection{Factors for Promoting and inhibiting the Legislation Body in the Formulation of Population Qanun}

\section{a. Push Factor}

1) Education

Factors that cause the weak role of the DPRA in carrying out its functions, namely the function of legislation, supervision, and budget due to the weakness of the political system and individual factors (HR) as political actors. In the behaviorism approach, it is the individual who is seen as actually carrying out political activities, whereas the behavior of political institutions is basically the behavior of individuals with certain patterns. Therefore, to explain the behavior of an institution that needs to be examined is not the institution, but the background of the individual who actually controls the institution. This can be seen from each individual level of competency. This competency is highly dependent on the ability, skills, expertise and knowledge of each of its members in the fields related to the duties of the DPRD. state the factors that influence the competence of DPRD members as follows:

a) Ethics and morals have not been determined;

b) Member recruitment system;

c) The quality of education and experience of members;

d) The low motivation of members for the benefit of the people, and

e) Government system used.

Thoha further identified the individual problems of DPRD members and the problems of DPRD institutions. These issues include issues based on the quality of individual DPRD members:

a. The quality of human resources in the DPRD is still relatively low, generally lacking experience in government.

b. The recruitment process is not based on individual competence, but based on closeness to party management.

c. Meritocracy considerations are not used against the qualifications of prospective DPRD members.

d. Still often sounds tempted to play money (moral).

e. DPRD members are less able to display their legislative abilities and show more oral skills in interrupting rather than making policy regulations.

Education is very closely related to knowledge. Indirectly, education can affect the mindset and behavior of board members. The developing world demands education to always adjust and become the locomotive of the nation's democratization and civilization process. Likewise the importance of education for members of the council so that the nation's reform process runs in accordance with its functions at the legislative level. Moreover, the requirements to become a member of the Aceh Parliament are minimum senior high school education and / or equivalent. That is why there are demands from the community so that members of the Aceh DPR can improve their quality both in terms of education and experience which will certainly have an impact on the critical power of addressing public issues, 


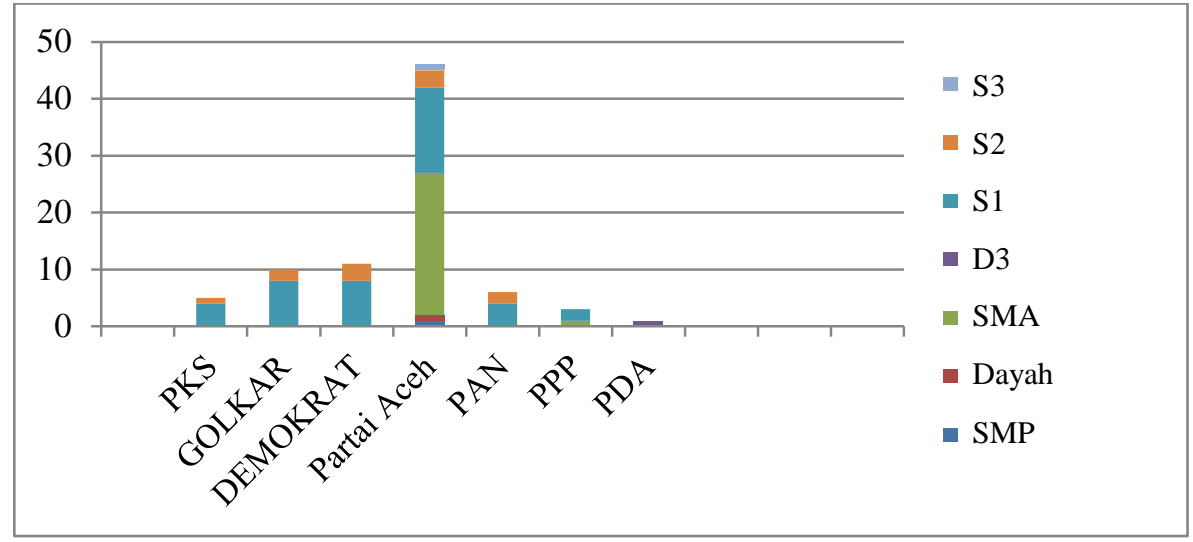

Figure 1. Level of Education

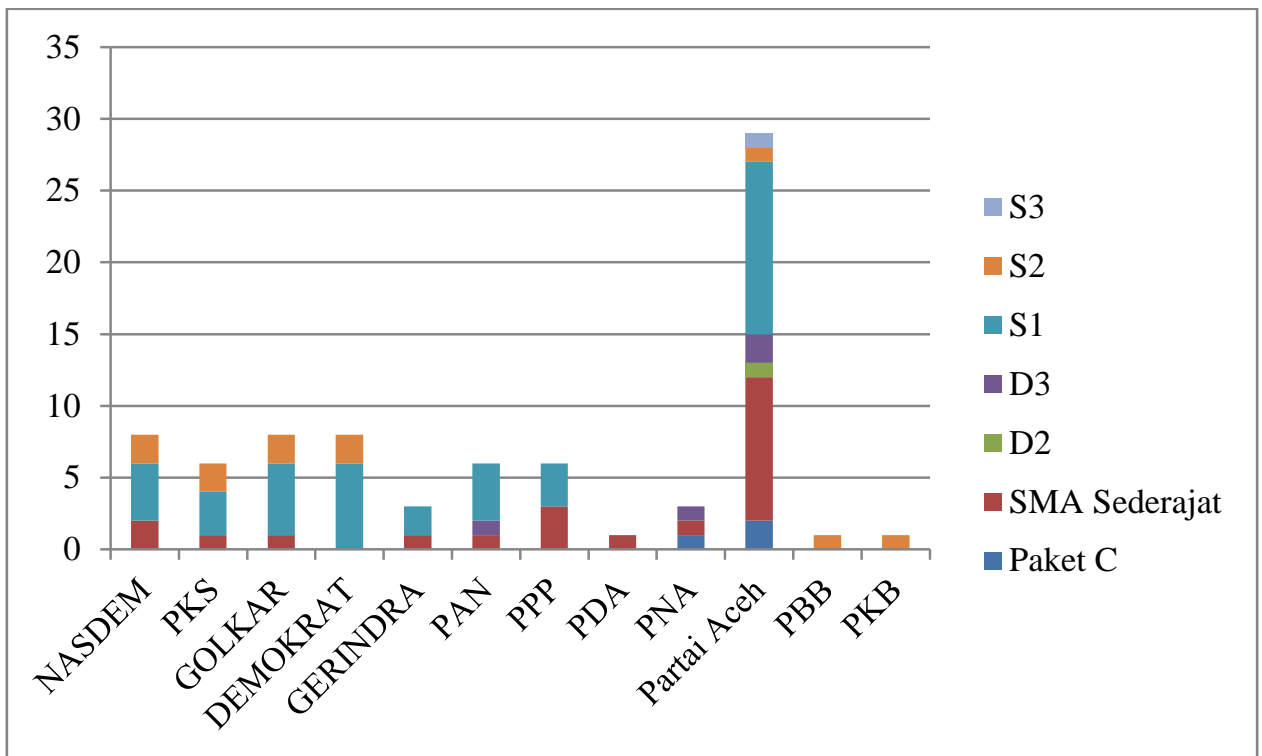

Source: Aceh DPR Secretariat, 2020

Figure 2. Level of Education

In addition, the slow process of ratification of the Aceh Population and Administration qanun required by the community at this time is also due to the weakness of the academic paper, therefore it is necessary to have a more comprehensive joint study and can be used for at least 5 to 10 years. Discipline of Aceh DPR members is still lacking, marked by the low level of attendance during Qanun discussions, so that sometimes the Qanun discussion meetings are delayed. Even in several meetings, the presence of experts is even more dominant than members of the board itself.

2) Planning and Coordination

According to Nugroho, it was stated that: DPRD and Local Government in the initial stage need to understand what the meaning of the legislation itself. Perda (qanun) is not just a text formulated by the DPRD, but it is a principle that must be obeyed by all actors in governance and development[7]. So that in the formulation of regional regulations the DPRD and Pemda are required to take into account interests at the regional, regional or national level. So that there is a series of coordination steps that need to be passed so that the law can be formulated properly and its implementation can be effective.

Every Qanun submitted by the Executive institution to the Legislature must first be coordinated with the draft Qanun so that discussion does not become an obstacle. Coordination between the Aceh DPR and the Government of Aceh jointly submits a list of draft Qanun to be made an agreement on the Aceh Legislation Program, both for 5 (five) years and for the priority of Submitting the Draft Qanun. 


\section{3) Secretariat Support}

The Aceh DPR Secretariat is an institution that specifically has the task of providing services to the Aceh DPR optimally and professionally, especially in carrying out legislative, budgetary and supervisory duties. In Law Number 11 of 2006 concerning the Government of Aceh, Article 108 paragraph (1) states that "the Aceh DPR Secretariat is led by the DPRA Secretary", whereas in paragraph (2) the Aceh DPR Secretary as referred to in paragraph (1) is appointed and dismissed by Governor after consultation with the leadership of the Aceh House of Representatives. The Aceh DPR Secretariat has a strategic position, which is to assist the Aceh DPRD in carrying out their daily duties and authorities.

The role of the Aceh DPR Secretariat in serving the legislative functions of the Aceh DPR mentioned in the Law of the Aceh Government Article 108 is then enriched in the Rules of the Aceh DPR Regulation, the role of the Aceh DPR Secretariat is added 4 (four) points from point (f) to point (i), each of which adds points clearly illustrates the magnitude of the Aceh DPR secretariat's role in serving the DPRA. As the role mentioned in the additional point (f) stating that the Aceh DPRD Secretariat can serve all the needs of the Aceh DPRD in order to carry out its functions and authorities as well as its duties, (g) the DPR Aceh Secretariat can participate in the Aceh DPRD meeting activities, make minutes and meeting notes, (h), the Aceh DPR Secretariat can provide technical and administrative considerations to the DPRA Chairperson,

b. Obstacle factor

1) Party Support in the Faction.

There is no support from parties for support to strengthen and provide understanding to members. During this time to use to ask for help from experts in the discussion of this qanun so we ask experts who understand and have insight about the qanun to be presented in the discussion of the qanun. It is time for improvement efforts to overcome the above problems. These efforts need to include changes to the recruitment system of members of the Aceh DPR, the Election system needs to be considered to be changed, the Aceh DPR / DPRK is returned as a Representative Body, not a Political Party representative. The Aceh DPR must display the functions of the legislative body a lot. Members of the Aceh DPR must have the ability to master knowledge, must be able to make laws or regulations called Legal Drafting andunderstanding the substance of the Qanun material which will be prepared by analyzing philosophical, juridical, and sociological aspects.

National and local political parties must provide the human resources of their members who will occupy the people's representatives. The education and training of Aceh DPR members must be carried out by Political Parties to strengthen competency as board members. The recruitment of members of the Aceh DPR must be based on individual competence not because of closeness to the political party elite. Being a member of the board must have mastery in making regulations, budgeting and supervision as well as morals must be a primary consideration.Before the members of the council were supposed to be appointed, they were first provided material on the Auth, Legal, and Community Knowledge. However, to date the quality of the competencies of elected legislators still needs to be questioned. The coaching system is still weak from political parties when preparing cadres to sit in parliament both at the Provincial and Regency / City levels.

2) Society participation

In the discussion stage the community can be involved in the hearing meeting this matter is mentioned in Article 25 paragraph 1 letter $b$. Communities that will be affected by the regulations discussed are invited for input. In addition to being invited by the legislature, the public can also ask the legislature to be invited to the hearing forum in order to provide input.

Referring to the reality of the draft Qanun that has been carried out so far, community involvement is still not a necessity. Even if there is public involvement, it tends to be the result of an approach.

Business actors feel they are not involved in discussing the draft Qanun or their involvement is minimal. However, in this public engagement there is still no guarantee that what is the aspirations of the people will be written in the final Qanun product. The preparation of the Qanun emphasizes more on the technical process and not on the substance to be compiled or what interests are brought by the Qanun. In the end, it is not uncommon for conflict to arise on the part where the Qanun will be applied later.

The management of socialization only fulfills the formal aspects, cannot guarantee whether stakeholder input is taken into account in the Qanun draft during the discussion. The most important thing is ensuring the suitability of the Qanun design with the development objectives to improve the welfare of the community, improving community services and increasing the competitiveness of the region, because the people who know the development needs of their region best. 


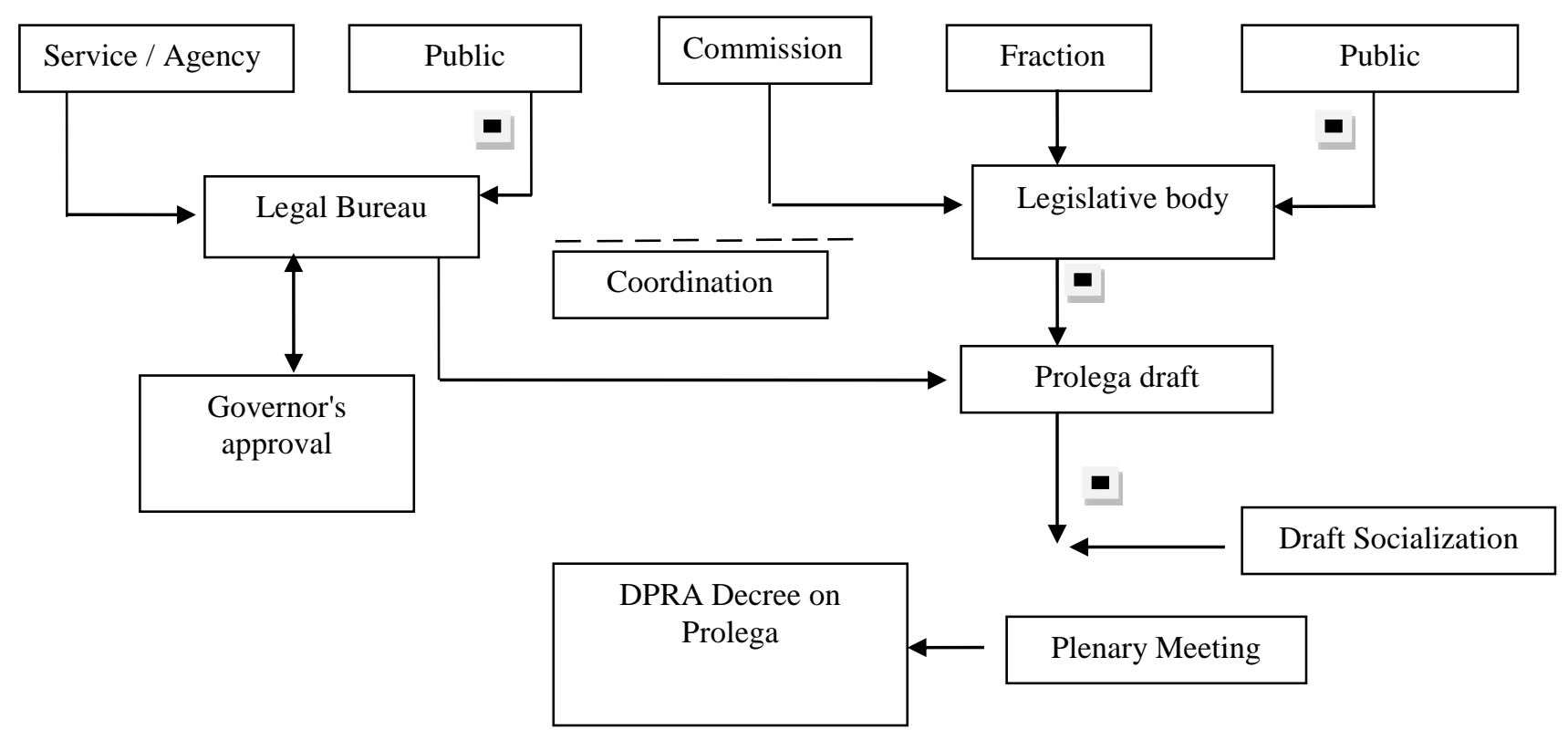

Figure 3. Aceh Legislation Program

Source: Library of the Aceh DPR Secretariat "A Pocket Book on: Everything about Prolega" (Aceh Legislation Program) prepared by the Author in 2020.

\section{CONCLUSION}

1) The Legislative Body is a grouping of DPRA members to functionally carry out tasks related to the formation of a draft Qanun and other regulations in a planned, integrated and systematic manner.

2) The function of the Legislative Body compiles a legislation program that lists qanun draft sequences for 1 (one) 5 (five) year membership period, prepares a DPRA initiative qanun draft based on priority programs that have been established annually and five years, which is an initiative, processing, planning and discussing and ratifying the Aceh Qanun. Legislative involvement in the formulation of public policy must start from the process of identifying problems and community needs that need to be prioritized for handling. So that the Qanun is not just a text formulated by the Aceh Parliament, but is a principle that must be obeyed by all governance actors in the region and its people.

\subsection{Theoretical Implications}

The findings of the study show that recognition and subsidiarity in the formulation of policies in the formulation of the Aceh Population Qanun are the duties and functions of the legislature and the government in planning, designing the qanun, discussing and defining the hallmark in producing various policies and rules for the benefit of the community by involving community groups. This finding supports Dunn's theorymentioned, the policy formulation process can be carried out through seven stages as follows[8]:

1) Problem Study. The aim is to find and understand the nature of the problem of a problem and then formulate it in a causal relationship. The Aceh Population Qanun is one of the basic needs in supporting the implementation of Aceh's development program, based on studies and analysis conducted by the government, a policy is proposed in order to regulate and manage population data to facilitate the government in improving social welfare. The Aceh Population Qanun was born on the basis of studies and analyzes conducted by related agencies which were then discussed together with the legislature to achieve equitable development programs.

2) Goal Setting is the stage to find goals to be achieved through public policy that is immediately formulated. Formulation in formulating policies and rules, one of which is the Aceh Population Qanun with stages that are jointly drafted together between the legislative and the government from planning, design, discussion, public hearings, comparative studies, consultations to discussions at the commission and plenary level are as efforts so that the results of a policy are accepted by the community without rejection.

3) Alternative formulation is a number of problem solving solutions that may be applied to achieve the goals that have been set. 
4) Modeling is a simplification and reality of the problems faced which are manifested in a causal relationship. Models can be built in various forms, for example schematic models, mathematical models, physical models, symbolic models and so on.

\subsection{Practical Implications}

Based on the results of this study several practical implications can be presented to the parties concerned with the phenomenon of policy formulation in the formulation of population qanun are:

1) In the formulation of the Aceh Population qanun policy formulation the involvement of the government, legislature, community groups and related institutions is very good, but it needs to be done in the implementation of each policy formulation is to increase discipline so that the formulation of a policy runs in accordance with the targets that have been planned and determined.

2) The ongoing consolidation of the regional government and legislature (Baleg) is maintained so that the implementation of the planning, scope, discussion and plenary of various policies continues to run well, so that all the resulting regulations are of high quality and accepted by the community.

3) It is necessary to improve the quality of Human Resources (HR) especially members of the Legislature and Commission in the DPRA, so that the results of policies and regulations made can be used in the next 15 years. HR improvement through various trainings in understanding various regulations and sensitive social conditions, one of which is the Policy Formulation in the formulation of the Aceh Population Qanun.

\subsection{Suggestions}

The results of this study are expected to be used for:

1) Theoretical use, is the author's contribution to the development of Public Administration, especially policy studies in developing concepts, understanding, and implementation to realize the independence of Public Administration, especially related to the issue of the function of the Aceh Legislative Body in the formation of the Qanun.

2) Practical Uses, provides information and contribution of ideas and input to decision makers at the regional level in realizing equality, levels and proportions in the Aceh Qanun Policy.

3) Every change in a product of the Law on Legislative Institutions should be directed to the process of political dynamics towards prosperity by considering the principles of efficiency, appropriateness, and fairness so that the resulting regulatory products can reflect that direction, so that it is more efficient, economical and reaches the target, rather than backward in terms of service. The function and role of the Aceh DPR is adjusted to the development of the dynamics of society as a constituent, including the resources of the Aceh DPR, must be better and increase, especially in terms of quality, so that people's representatives truly represent the aspirations of the people who voted for it, not to focus too much on the policies of their parties.

4) To determine a member of the Aceh DPR to be included in one of the tools of the DPR Aceh needs to be taken into account the ability, experience, insight, including the field of science occupied / mastered. Thus members of the Aceh DPR will become professionals in their duties and fields as a tool that they will enter.

5) The function of the Legislative Body must be professional with regard to the existence of carrying out the functions of the Legislative Body, Banleg's ability must be able to place his position in determining the Legislative Program every year to be fully discussed carried out by each commission based on the Priority of the Qanun.

6) FormationQanun is an integral part of regional development needs to adjust to the regional development planning framework. Individual members of the Aceh DPRD are charged with responsibility for producing truly high quality legislation products in accordance with development planning documents, synergy oriented to the needs of the community.

\section{REFERENCES}

1. Undang-undang Nomor 23 Tahun 2006 tentang Administrasi Kependudukan.

2. Undang-Undang Nomor 11 Tahun 2006 tentang Pemerintah Aceh.

3. Undang-Undang Nomor 12 Tahun 2011 tentang Pembentukan Peraturan Perundang-Undangan.

4. Siedman, Robert. 1971. Law, Order, and Power. Philippines: Addison-Wesley Publishing Company, Inc.

5. Qanun Aceh No. 6 Tahun 2008 Tentang Penyelenggaraan Administrasi Kependudukan.

6. Peraturan Pemerintah Nomor 59 Tahun 2015 tentang Keiikutsertaan Perancang Peraturan Perundang-Undangan Dalam Pembentukan Peraturan Perundang-Undangan dan Pembinaannya.

7. Nugroho, Riant. 2010. Dinamika Kebijakan dan Analisa Kebijakan. Jakarta: PT. Elex Media Komputindo.

8. Dunn, William N. 2003. Pengantar Analisis Kebijakan Publik Edisi Kedua. Yogyakarta: GadjahMada Univesity Press. 